UDC 349.2

DOI https://doi.org/10.32782/2524-0374/2021-8/43

\title{
PUBLIC-PRIVATE PARTNERSHIP IN THE AGRICULTURAL SPHERE: PROBLEMS OF LEGAL COVERAGE
}

\author{
ДЕРЖАВНО-ПРИВАТНЕ ПАРТНЕРСТВО В АГРАРНІЙ СФЕРІ: \\ ПРОБЛЕМИ ПРАВОВОГО ЗАБЕЗПЕЧЕННЯ
}

Firsova N.V., lawyer

ORCID ID: 0000-0002-4810-3522

The article is devoted to the coverage of one of the current theoretical and methodological problems of agrarian law - the attraction of additional investment flows for the implementation of agricultural policy. The agricultural sector of the economy tends to increase the share of value in total GDP, increasing the share of food products in the structure of Ukrainian exports. In addition, it demonstrates increased resilience of agricultural exports to economic crises.

At the same time, for the successful development of the agricultural sector of Ukraine's economy, it is necessary to promote the attraction of significant investment and innovation resources, which can be obtained through the use of existing models of public-private partnership.

Public-private partnership in the agricultural sector should be considered as a long-term comprehensive model of mutually beneficial relations of public and private sector in the form of delegation by the state to a private partner of certain functions, rights and responsibilities to implement public, private and public interests (effective development of the agricultural sector, support of agricultural producers, implementation of food security, attraction of innovative technologies, creation of public goods, etc.) on the basis of construction and operation of infrastructure facilities.

The main types of PPP projects in the agricultural sector are identified: partnerships aimed at developing value chains; partnerships for collaborative research, innovation and technology transfer; partnerships to create market infrastructure; partnerships to provide business development services to farmers and small agricultural enterprises.

The directions of PPP implementation in the agricultural sector are determined: ensuring the social character of functioning of infrastructural objects of agricultural sphere; use of cluster approach and special economic zones; formation of human potential; development of science and education in areas related to the agricultural sector; expanding access.

Based on the priority ways of development of innovations and science, directions of PPP projects implementation in the agricultural sector, the following are determined: expansion of infrastructure (production, logistics, energy and reclamation); development of production of complex fertilizers, plant protection products; reduction of environmental pollution; formation of agri-food chains on the basis of the cluster approach and creation of technoparks; projects in the field of education and science of agricultural direction; increasing the level of use of renewable energy; ensuring the production of organic agricultural products, meat and dairy products; development of seed production and biotechnology.

Key words: public-private partnership, agrarian sphere, investment, infrastructure, agricultural products.

Стаття присвячена висвітленню однієї з актуальних теоретико-методологічних проблем аграрного права - залученню додаткових інвестиційних потоків для реалізації аграрної політики держави. Аграрний сектор економіки має тенденції до зростання частки вартості у загальному ВВП, нарощення частки продовольчих товарів у структурі українського експорту. До того ж він демонструє підвищену стійкість експорту сільськогосподарської продукції до економічних криз. При цьому для успішного розвитку аграрного сектору економіки України необхідно сприяти залученню значних інвестиційних та інноваційних ресурсів, які можливо отримати за рахунок використання наявних моделей державно-приватного партнерства.

Державно-приватне партнерство в аграрній сфері слід розглядати як довгострокову комплексну модель взаємовигідних відносин суб'єктів державного та приватного сектору у вигляді делегування державою приватному партнеру окремих функцій, прав та відповідальності з метою реалізації державних, приватних та суспільних інтересів (ефективний розвиток аграрного сектору, підтримка сільськогосподарських товаровиробників, реалізація продовольчої безпеки, залучення інноваційних технологій, створення суспільних благ тощо) на основі будівництва й експлуатації інфраструктурних об'єктів.

Виокремлено основні види проєктів ДПП в аграрному секторі: партнерства, спрямовані на розвиток ланцюгів доданої вартості; партнерства для спільних досліджень, інновацій і передачі технологій; партнерства для створення ринкової інфраструктури; партнерства для надання послуг з розвитку бізнесу фермерам і малим сільськогосподарським підприємствам.

Визначено напрями впровадження ДПП в аграрному секторі: забезпечення соціального характеру функціонування інфрраструктурних об'єктів сільськогосподарської сфери; використання кластерного підходу та особливих економічних зон; формування людського потенціалу; розвиток сфери науки та освіти за напрямами, пов'язаними з аграрним сектором; розширення можливості доступу.

Виходячи з пріоритетних шляхів розвитку інновацій та науки, напрямами реалізації проєктів ДПП в аграрному секторі визначено: розширення інфраструктури (виробничої, логістичної, енергетичної та меліоративної); розвиток виробництва комплексних добрив, засобів захисту рослин; зменшення забруднення навколишнього середовища; фрормування агропродовольчих ланцюгів на основі кластерного підходу та створення технопарків; проєкти у сфері освіти та науки аграрного спрямування; підвищення рівня використання відновлювальної енергетики; забезпечення виробництва органічної сільськогосподарської продукції, м'ясної та молочної продукції; розвиток насінництва та біотехнологій.

Ключові слова: державно-приватне партнерство, аграрна сфера, інвестування, інфрраструктура, сільськогосподарська продукція.

The key role of the agricultural sector of the economy is to form food security, increase the export potential of the state, providing agricultural products to the domestic market. Therefore, the development of the agricultural sector of Ukraine's economy requires the state to find effective approaches to alternative forms of attracting additional resources that will enable the realization of existing sectoral potential. In 2021, UAH 4.5 billion was allocated from the general fund of the state budget for financial support of agricultural producers [1], which does not provide the necessary development of the industry. According to some estimates, the agricultural sector in the period 2020-2030 will need about 46 billion dollars US investment attraction [2]. Thus, according to preliminary estimates, public investment does not leave the needs of the industry. This necessitates the search for new investment instruments, alternative to the state. One of the most effective means of investing in strategic areas of the economy is the mechanism of public-private partnership.

Analysis of the implementation of public-private partnership (PPP) projects in the infrastructure sectors proves the feasibility and significant public results of cooperation between the state and the private sector. This experience is beginning to be used in the agricultural sector, which allows to provide the industry with the necessary resources and competencies that can increase agricultural production, increase the efficiency of use of funds.

Given the impossibility of implementing certain socioeconomic tasks within the resources of only the public or private sector, the need for timely response to change, ensuring 
a comprehensive solution, based on the specifics of the agricultura sector and existing sectoral strategic documents, approaches to public sector policy should use competitive management models, principles of project management and innovation tools based on models of partnership of public and private forms of ownership in the agricultural sector.

In the current conditions of global economic development and population growth, the dynamics of demand for agricultural products is increasing. It should be noted that in 1995-2018, world food exports grew by an average of $3.4 \%$ per year, and agricultural exports increased by an average of $1.9 \%$ per year [3]. The agricultural sector of the economy continues to play a key role in increasing food resources, strengthening positions in foreign commodity markets, and ensuring national security. Global value added created by agriculture, forestry and fisheries increased by $68 \%$ in real terms from 2000 to 2018 , showing an increase of 1.4 trillion dollars USA compared to 2000. The total production of primary crops increased by almost $50 \%$ from 2000 to 2018 to 9.1 billion tons. World meat production in 2018 reached 342 million tons, which is $47 \%$ more, or 109 million tons compared to 2000 . The area of land equipped with irrigation systems reached 339 million hectares in 2018 , which is $17 \%$ more than in 2000 . The monetary value of world food exports increased in 2000-2018 from 380 billion dollars US to almost 1.4 trillion US dollars in 2018, with significant growth in all food product groups [4]. These data show an increase in volumes, which in turn leads to the constant involvement of workers in agriculture, which remains one of the largest sources of employment in the world. According to the Food and Agriculture Organization (FAO), the world's population is expected to grow by almost $30 \%$ to 9.1 billion in 2050 , and this will require a $70 \%$ increase in food production and a $50 \%$ increase in agricultural investment, meeting the needs of people [5]. It is expected that by 2024 the growth of demand for agricultural products [6]. If we compare Ukraine with some countries in terms of the share of the value of agriculture, forestry and fisheries in total GDP for the period 2005-2018, we can see that in Ukraine this percentage tends to grow steadily. The agricultural sector of Ukraine accounts for $15 \%$ of employment. Exports of agri-food products account for about $40 \%$ of Ukraine's total exports [7]. Ukraine is expected to steadily increase its share of world trade and reach $12 \%$ of world exports in 2029 . Ukraine is projected to increase yields by $1.5 \%$ per year, subject to increased crop rotation combined with best agricultural practices and abandonment of unproductive lands [8].

Due to the increase in agricultural productivity in the last decade, the share of food products in the structure of Ukrainian exports has doubled to $47 \%$ in 9 months of $2020(21 \%$ in 2010). An important characteristic of the agricultural sector is the higher resilience of agricultural exports to crises in the economy, which reflects the low elasticity of demand for food by income (with declining incomes, demand for it decreases more moderately compared to other goods). As a result, in the structure of Ukrainian exports, a high share of food products served as a kind of buffer during the economic crisis in 2020 [9]. Thus, we can say that the agricultural sector plays a significant role in the development of Ukraine, but further action should include attracting investment resources, the introduction of new technologies with high added value, the transition to modern forms of management. Indeed, the reduction in the share of investment in agriculture and their physical volume threatens the food security of the country [10]. One of the ways that can strengthen the position of the agricultural sector in Ukraine, provide additional resources and innovative approaches to the development of the industry can be a modern approach to public-private sector - public-private partnership.

The emergence of PPPs in agriculture is a response to the difficulties in providing the public good, such as food security, environmental protection and the viability of rural areas [11]. PPP can be considered as a new form of public administration, which provides for structured contractual cooperation between public and private stakeholders in the design, planning, construction and operation of socially important infrastructure, in which partners agree on the distribution of risks, costs, benefits, resources and responsibility, increasing the efficiency of public funds.

The implementation of PPP is aimed at ensuring sustainable economic development by: balancing economic, environmental and social needs; overcoming poverty by creating jobs; meeting the basic needs of people, which requires economic growth and social equality; minimizing the impact of the environment on development projects; optimizing the use of available resources, including natural resources. Issues that should be reflected in the state policy of agricultural sector development with the use of PPP projects: providing the necessary compensation; monitoring the implementation of PPP projects; assessment of possible positive and negative impacts of the project; exploring opportunities to improve the environment; promoting the development of social, social and cultural practices [12]. If we consider the use of publicprivate partnership in the agricultural sector, the latter defines the model of interaction between public institutions and private partners (agricultural firms and farmers), which is designed to achieve sustainable agriculture, where public benefits, investment and risk sharing are set active role of all partners at different stages during the life cycle of the PPP project [13].

PPP serves as a particularly necessary tool of systemic public policy in the field of agricultural and technological innovation, which provides stimulating functions: knowledge development, networking, management [14]. PPP in the agricultural sector is seen as an institutional and organizational alliance of public authorities and private business to implement national and local priority projects, which is carried out on the principles of mutual benefit and consolidation of joint efforts [15]. Areas of implementation of PPP projects in the agricultural sector, which have significant potential may be: expansion of production (greenhouse complexes, meat processing, cereals [16]), logistics (road network, warehouses, storage), energy and reclamation (irrigation) [17] infrastructure; development of production of complex fertilizers, plant protection products, etc.; use of innovative technologies to reduce and prevent environmental pollution, implementation of approaches that prevent globalization and climate change, stimulating soilsaving agriculture; formation of agri-food chains with high added value from producer to consumer based on a cluster approach; creation of technology parks, which combine research institutions, educational institutions of agricultural specialization, research and production structures, etc.; ensuring animal health and welfare during their keeping, minimizing the manifestations of epidemics, etc.; projects in the field of education and science related to the agricultural sector [18]; increasing the level of use of renewable energy through the development of technologies for biofuel production (growing energy crops, use of agricultural waste); ensuring the production of organic agricultural products, meat and dairy products; development of seed production and biotechnology based on innovations in genetic engineering and sequencing. Developing these areas of implementation of PPP projects, it is possible to increase the profitability of activities in the agricultural sector, the development of the environment for small and medium-sized businesses in the agricultural sector, which creates products for domestic and foreign consumption. In order to unleash the existing potential of the agricultural sector, a high level of investment in the agricultural value chain is needed. Such investments include research and technologies that increase productivity, human resource development and infrastructure for the transport, storage, processing and marketing of agricultural products. PPP in the agricultural sector can provide: a PPP risk allocation function that can help structure projects to address a range of sectoral risks; benefits 
related to increased efficiency and market access through the use of innovative technologies and high management and marketing skills of the private sector; the results of food security and stimulating the development of value chains, which include small farmers and small and medium-sized agricultural enterprises as key suppliers of raw materials for agribusiness [19].

The scientific literature defines the typology of four general types of PPP projects in the agricultural sector: partnerships aimed at developing value-added chains in agriculture to ensure access to domestic and foreign markets (VCD); a partnership for joint research in agriculture, innovation and technology transfer, which is created for the commercialization of innovative technologies aimed at increasing productivity and market access (ITT); partnership for the construction and modernization of market infrastructure, aimed at the development of shopping centers, warehouses, logistics systems (MI); partnerships to provide business development services to farmers and small agricultural enterprises, including the development of market information systems, subsidies for business development services (BDS) [19; 20]. It should be noted some examples of various forms of PPP implementation in the agri-food sector of the world's leading countries and domestic practice. Thus, in French irrigation agriculture, individual PPP projects were implemented.

The CACG/ASA project was implemented on the basis of a concession agreement and provided for the expansion of irrigated areas by 200.000 hectares for further cultivation of corn, vegetables and fruits. The Société du Canal de Provence (SCP) is another French concession project that seeks to rehabilitate 80.000 hectares of irrigation networks and further grow vegetables and fruits. The created technological park "Agrotechnopark" (Kyiv) can be called a domestic example of interaction between the state and a private owner, in which projects in the field of generating complexes using biofuels are implemented together with partners; creation and modernization of agro-industrial and processing productions on the basis of the newest technologies; development of systems to increase soil fertility; technologies of selection activity in plant growing and animal husbandry, etc. [21]. The regional agro-industrial innovation cluster "Agroinnovation" was created in Rivne, the founders of which were representatives of public authorities, scientific and educational institutions, industrial enterprises and innovation structures. This cluster aims to combine opportunities and implement joint activities for the development and implementation of innovative projects in the agro-industrial complex of the region [22]. The implementation of strategic imperatives should take place through the application of systematic measures of strategic management of public-private partnership in the agricultural sector with the development and implementation of appropriate standards of strategic management [23]. The introduction of the mechanism of public-private partnership in the agricultural sector should become the object of strategic management within the general economic policy of the state, which will contribute to the stability of institutional regulation.

It is considered necessary in the development of the Strategy for the development of the agricultural sector to define publicprivate partnership as one of the mechanisms for implementing long-term priorities and tasks, the result of which should be to eliminate existing imbalances and focus on dynamic and sustainable development [15]. The tools for implementing the state policy aimed at the development of the agricultural sector on the basis of the implementation of PPP projects should be: the creation of technology parks and business incubators; implementation of agricultural cluster projects and value chains; attraction of venture capital and investment funds; compensation of interest rates on loans for infrastructure construction. The use of public-private partnership tools in the agricultural sector has significant advantages: the implementation of socially important infrastructure projects in the agricultural sector of the economy by attracting private sector resources; increasing the competitiveness of the industry [24]; modernization of fixed assets, material and technical and raw material base of agricultural sector enterprises; increasing agricultural productivity and creating new jobs, which will increase the revenue side of the budget [25]; increasing the quality of agricultural products; restoration of the environment [15]; additional opportunities for state regulation and implementation of comprehensive programs in the agricultural sector; increasing technological, financial and export potential in agriculture, including at the regional level. Private business, in turn, can receive direct support from government agencies in the implementation of PPP projects in the agricultural sector; state guarantees for longterm investment; opportunities for innovation in agriculture; sectoral benefits and preferences.

Areas of PPP implementation in the agricultural sector can be considered: ensuring the social nature of the functioning of infrastructure facilities based on balancing the human potential of the agricultural sector; use of cluster approach and special economic zones, which will optimize management and processes through the localization of objects; formation of human potential [26], including rural areas related to the agricultural sector; development of science and education in areas related to the agricultural sector; expanding the access of the private sector to financial resources with preferential terms of receipt. It should be noted that the successful achievement of the goal of public-private partnership projects in the agricultural sector depends on the implementation of public policy aimed at risk management, which should include interest rate fluctuations, force majeure (natural disasters, man-made factors), changes in legislation, changes in the tax system, underdeveloped financial market. In the process of implementing PPP projects, it is necessary to pay attention to the main factors that must be taken into account when formulating the policy of agricultural sector development through public-private partnership should be considered: limited capacity of the state budget to implement socially important infrastructure projects in the agricultural sector, political environment, regulation of market conditions, macroeconomic policy, institutional quality, legal system.

It should be noted that the agricultural sector of the economy tends to increase the share of value in total GDP. At the same time, for the successful development of the agricultural sector of Ukraine's economy, it is necessary to promote the attraction of significant investment and innovation resources, which can be obtained through the use of existing models of publicprivate partnership.

In general, there are many unresolved issues of legal support of the agricultural sector. However, we will focus on such basic ones. It should be emphasized that the norms of direct action in public-private partnership in the field of agricultural relations is the Law of Ukraine "On Public-Private Partnership". In accordance with the provisions of this Law, public-private partnership is defined as cooperation between the state of Ukraine, the Autonomous Republic of Crimea, territorial communities represented by the relevant state bodies, which in accordance with the Law of Ukraine "On Management of State Property" property, local governments, the National Academy of Sciences of Ukraine, national branch academies of sciences (state partners) and legal entities, except for state and communal enterprises, institutions, organizations (private partners), which is carried out on the basis of an agreement in the manner prescribed by law and meets the characteristics of public-private partnership defined by this Law.

However, in accordance with Part 2 of Article 3 of the Law of Ukraine "On Management of State Property" land is not an object of state property management. Thus, land that is on the right of permanent use in state-owned enterprises of the agricultural sector of the economy and there are no legal grounds for establishing control over it by the governing 
bodies to which these enterprises are subordinated. In addition, the scope of application of the Law of Ukraine on PPP does not apply to land plots of state-owned agricultural enterprises.

Thus, today, due to the existing gap in the legislation, potential investors do not have a reliable legal mechanism for investing in the agricultural sector. There are also no guarantees of return on investment in the course of sustainable long-term investment in the activities of state-owned agricultural enterprises.

It should be noted that during the thirty years of independence in Ukraine there is virtually no state-owned agricultural enterprise with sufficient material and technical base, which would allow to cultivate land and earn a stable income. Forward contracts, financial or commodity agricultural receipts solve only situational issues that are not aimed at the development of the enterprise as a whole. These companies are constantly on the verge of bankruptcy.

We suggest that as an alternative we can consider the application in economic activity of the Resolution of the Cabinet of Ministers of Ukraine No. 296 of 11.04.2012, which approved the Procedure for concluding state enterprises, institutions, organizations and companies in the authorized capital of which the state exceeds 50 percent agreements on joint activities, agreements of the commission, power of attorney and property management. According to this normative legal act, an economic entity that has expressed its intention to enter into an agreement submits to the central executive body to which it belongs, another entity of management of state property (application for approval of the contract together with the relevant documents).

In accordance with paragraph 4 of this Resolution, the governing body submits in the prescribed manner for consideration by the Cabinet of Ministers of Ukraine an agreed draft decision approving the conclusion of the contract together with certain documents.

In the event that the Cabinet of Ministers of Ukraine decides to approve the conclusion of the agreement, the governing body shall take measures to ensure its conclusion by the business entity in accordance with the requirements of the legislation.

However, such a long-term bureaucratic mechanism objectively makes it impossible to use it in the conditions of shortterm seasonal work and the specifics of the production process in the need to quickly make the necessary management decisions.
As of the beginning of 2020, when the state-owned enterprise was not transferred for privatization, according to the State Geocadastre, 10.4 million hectares of land are in the structure of state ownership. Of these, 0.7 million hectares of land are in the occupied territories, which is $7 \%$. On the whole territory of Ukraine, 1.7 million hectares or $16 \%$ have been transferred to OTG. According to the government's plans, more than 100 agricultural enterprises will be sold in two years. According to Acting Minister of Economic Development Pavlo Kukhta, more than 3.700 state-owned enterprises in the country, of which 1.000 have been identified for privatization, and 530 were transferred to the State Property Fund last year.

In the structure of land ownership, the main amount of land is privately owned, it is about 31 million hectares, in state and communal ownership are 10.4 million hectares. At the same time, about a third of the land, 32.7 million hectares is under arable land [27].

Thus, the state has a powerful and in-demand resource that can be attractive to business, but there is no political will to create a simple, transparent PPP mechanism in the agricultural sector that would be mutually beneficial to all participants

Public-private partnership in the agricultural sector can be considered as a long-term comprehensive model of mutually beneficial relations of public and private sector in the form of state delegation to the private partner of certain functions, rights and responsibilities to implement public, private and public interests (effective development of the agricultural sector agricultural producers, implementation of food security, attraction of innovative technologies, creation of public goods, etc.) on the basis of construction and operation of infrastructure facilities.

Based on the priority ways of development of innovations and science, the directions of PPP projects in the agricultural sector, the following are determined: expansion of infrastructure (production, logistics, energy and reclamation); development of production of complex fertilizers, plant protection products; reduction of environmental pollution; formation of agri-food chains on the basis of the cluster approach and creation of technoparks; projects in the field of education and science of agricultural direction; increasing the level of use of renewable energy; ensuring the production of organic agricultural products, meat and dairy products; development of seed production and biotechnology.

\section{BIBLIOGRAPHY}

1. Про Державний бюджет України на 2021 рік : Закон України № 1082-ІХ від 15.12.2020р. База даних «Законодавство України». / BP України. URL: https://cutt.ly/pnfrUxS (дата звернення: 11.07.2021).

2. Україна - світовий супермаркет екологічних продуктів. Український інститут майбутнього. URL: https://cutt.ly/4bMHWmq (дата звернення: 11.07.2021).

3. The State of Agricultural Commodity Markets 2020. Agricultural markets and sustainable development: Global value chains, smallholder farmers and digital innovations. FAO. Rome, 2020. DOI: https://doi.org/10.4060/cb0665en (дата звернення: 11.07.2021).

4. World Food and Agriculture - Statistical Yearbook 2020. FAO. Rome, 2020. URL: https://cutt.ly/ZnfrLDv (дата звернення: 11.07.2021).

5. Shih-Hsun Hsu T., Ching-Cheng C., Nguyen T.T. APEC Survey Report on Feasible Solutions for Food Loss and Waste Reduction. 2018. Singapore, AsiaPacific Economic Cooperation (APEC), 2018. 71 p.

6. OECD-FAO Agricultural outlook 2015. Paris: FAO, OECD Publishing, 2015. URL: www.fao.org/3/a-i4738е.рdf (дата звернення: 11.07.2021)

7. Agricultural Policy Monitoring and Evaluation 2020. OECD Publishing. Paris, 2020. DOI: https://doi.org/10.1787/928181a8-en (дата звернення: 11.07.2021).

8. Agricultural Outlook 2020-2029. Paris: FAO, OECD Publishing, 2020. DOI: https://doi.org/10.1787/1112c23b-еn (дата звернення: 11.07.2021)

9. Інфрляційний звіт. Жовтень 2020 року. НБУ, 2020. URL: https://bank.gov.ua/monetary/report (дата звернення: 11.07.2021).

10. Zeldner A. The mechanism of public-private partnerships in attracting investment in agriculture. IOP Conference Series: Earth and Environmental Science. IOP Publishing. 2019. No. 274. P. 012056.

11. Yost M.A., Sudduth K.A., Walthall C.L., Kitchen N.R. Public-private collaboration toward research, education and innovation opportunities in precision agriculture. Precision Agriculture. 2019. No. 20(1). P. 4-18.

12. Rashed M. et al. Considerable Issues for Sustainable Public-Private Partnership Project. Res Manageria. 2011. Vol. 2. Issue 4. P. 57-65.

13. Gaffney J., Challender M., Califf K., Harden K. Building bridges between agribusiness innovation and smallholder farmers: A review. Global Food Security. 2019. No. 20. P. 60-65.

14. Hermans F., Geerling-Eiff F., Potters J., Klerkx L. Public-Private Partnerships as Systemic Agricultural Innovation Policy Instruments Assessing Their Contribution to Innovation System Function Dynamics. NJAS-Wageningen Journal of Life Sciences. 2019. Vol. 88. P. 76-95.

15. Косач І., Журман С. Державно-приватне партнерство в АПК України: стратегічні аспекти. Проблеми і перспективи економіки та управління. 2019. № 4(20). С. 127-136.

16. Kozin M., Pyrchenkova G., Radchenko E. Public-private partnership in the agricultural sector: empirical estimation by factorial characteristics. E3S Web of Conferences. 2020. No. 175. P. 130. 
17. Дідковська Л.І. Аналіз світових тенденцій поширення державно-приватного партнерства у зрошуваному землеробстві. Економіка АПК. 2019. № 7. С. 66-72. DOI: https://doi.org/10.32317/2221-1055.201907066 (дата звернення: 11.07.2021).

18. Латинін М.А., Заскалкіна О.М. Перспективи розвитку механізмів державного регулювання інституціонального середовища в аграрному секторі економіки України. Міжнародний науковий журнал «Інтернаука». 2017. № 10. С. 14-22.

19. Rankin M. et al. Public-Private Partnerships for Agricultural Transformation - Trends and Lessons from Developing Countries. The Emerald Handbook of Public-Private Partnerships in Developing and Emerging Economies. Emerald Publishing Limited, 2017. P. 191-219.

20. Reznik N. et al. Development of Public-Private Partnerships in The Agrarian Sector of Ukraine: Digitalization as a Priority. International Journal of Recent Technology and Engineering (IJRTE). 2019. No. 8(3). P. 275-281.

21. Безпрозванних О.О. Розвиток інфраструктурного забезпечення інноваційної діяльності промислового підприємства : дис.. .... канд. економ. наук : 08.00.04. Харків : НТУ «Харківський політехнічний інститут», 2020. 322 с.

22. Оніпко Т.А. Інноваційно-кластерний розвиток як чинник зростання конкурентоспроможності економічних систем : дис. ... канд. економ. наук : 08.00.01. Полтава : Вищий навчальний заклад Укоопспілки «Полтавський університет економіки і торгівлі», 2019.280 с.

23. Kosach I.A., Kholyavko N.I. The strategy for the development of public-private partnerships in agriculture in the context of food security. Innovative solutions in modern science. Dubai, UAE. 2016. No. 1(1). P. 12-17.

24. Латинін М.А., Заскалкіна О.М. Перспективи розвитку механізмів державного регулювання інституціонального середовища в аграрному секторі економіки України. Міжнародний науковий журнал «Інтернаука». 2017. № 10. С. 14-22.

25. Dudin M.N., Shakhov O.F., Vysotskaya N.V., Stepanova D.I. Public and Private Partnership: Innovation-Driven Growth of Agriculture at the Regional Level. Journal of Environmental Management and Tourism. Volume X, Winter. 2019. No. 7(39). P. 1435-1444.

26. Kruhlov V.V., Tereshchenko D.A. Public-Private Partnership as Tool for Developing Regional Labor Potential. Science and Innovation. 2019. No. 15(6). Pp. 05-13.

27. "Land Directory of Ukraine 2020" - a database of land fund of the country. URL: https://agropolit.com/spetsproekty/705-zemelniydovidnik-ukrayini--baza-danih-pro-zemelniy-fond-krayini. 